\title{
Evaluation of cinnamon extract effects on $c l b B$ gene expression and biofilm formation in Escherichia coli strains isolated from colon cancer patients
}

Faezah Kosari ${ }^{1}$, Mohammad Taheri ${ }^{1}$, Abbas Moradi ${ }^{2}$, Reza Hakimi Alni ${ }^{3}$ and Mohammad Yousef Alikhani ${ }^{1,4^{*}}$

\begin{abstract}
Background: Colon cancer is one of the most common malignancies and the fourth leading cause of cancerrelated mortality in the world. Colibactin, which is synthesized by the pks genomic island of E. coli interfere with the eukaryotic cell cycle. Cinnamon has an antimicrobial effect and considered as a colon cancer-preventing agent. The aim of the study was to evaluate the effects of cinnamon extract and cinnamaldehyde on $c l b B$ gene expression and biofilm formation in clinical isolates of $E$. coli.

Methods: Thirty E. coli carrying pks gene were isolated from the colon cancer patients, inflammatory bowel disease and healthy subjects. Antibiotic susceptibility was evaluated by disk diffusion method and the minimum inhibitory concentration of cinnamon essential oil and cinnamaldehyde by microdilution broth method. In vitro biofilm formation of E.coli isolates was monitored using a microtiter plate method. The presence of clbB, clbA and clbQ genes in E.coli isolates were evaluated by PCR. The effect of cinnamaldehyde and cinnamon essential oil on clbB gene expression was evaluated by Real-Time PCR.

Results: The highest antibiotic resistance was obtained with 94.4\% for ticarcillin-clavulanic acid, azithromycin, amoxicillin, and amikacin. The MIC for all clinical isolates was $32 \mathrm{\mu l} / \mathrm{ml}$ of cinnamon essential oil and the MIC of cinnamaldehyde was between 0.00002 to $0.03 \mu \mathrm{l} / \mathrm{ml}$. After exposure of isolates to cinnamon extract and cinnamaldehyde, 40 and $13.3 \%$ were weakly biofilm producers, respectively. The frequencies of $c l b B, c l b A$, and $c l b Q$ genes were 23.3, 23.3, and $26.7 \%$, respectively. The expression of $c l b B$ gene in the presence of the Sub-MIC concentration of cinnamon essential oil and cinnamaldehyde was decreased in 8 isolates compared to untreated isolates ( $p$-value $<0.05$ ).
\end{abstract}

Conclusions: The antibacterial activity of cinnamaldehyde and cinnamon essential oil allows the use of these herbal compounds for treatment or supplements in infections caused by E. coli and in patients with suspected colorectal cancer.

Keywords: E. coli, Cinnamaldehyde, Biofilm, Pks, clbB, Colon cancer

\footnotetext{
*Correspondence: alikhani43@yahoo.com; alikhani@umsha.ac.ir

${ }^{1}$ Microbiology Department, Faculty of Medicine, Hamadan University of Medical Sciences, P.O box: 6517838678, Hamadan, Iran

${ }^{4}$ Brucellosis Research Center, Hamadan University of Medical Sciences, Hamadan, Iran

Full list of author information is available at the end of the article
}

(c) The Author(s). 2020 Open Access This article is licensed under a Creative Commons Attribution 4.0 International License, which permits use, sharing, adaptation, distribution and reproduction in any medium or format, as long as you give appropriate credit to the original author(s) and the source, provide a link to the Creative Commons licence, and indicate if changes were made. The images or other third party material in this article are included in the article's Creative Commons licence, unless indicated otherwise in a credit line to the material. If material is not included in the article's Creative Commons licence and your intended use is not permitted by statutory regulation or exceeds the permitted use, you will need to obtain permission directly from the copyright holder. To view a copy of this licence, visit http://creativecommons.org/licenses/by/4.0/. The Creative Commons Public Domain Dedication waiver (http://creativecommons.org/publicdomain/zero/1.0/) applies to the data made available in this article, unless otherwise stated in a credit line to the data. 


\section{Background}

Colorectal cancer (CRC) is one of the most common cancers and causes of death in the world. Because of its high incidence and mortality rate, colorectal cancer is a major public health problem. There is increasing evidence that the mucosa-associated flora and their related products may be important in the pathogenesis of inflammatory bowel diseases, ulcerative colitis, and colorectal cancer via various mechanisms $[1,2]$. In gastrointestinal diseases, the rate of attachment of $E$. coli to intestinal mucus is increased in the ileum and colon [3, 4]. However, these patients have high levels of $E$. coli belong to B2 phylogroup, which induces more expression of $C E A$ $C A M 6$, a cancer marker, in the intestinal epithelial cells and intensifies the inflammation [5].

Some E. coli strains carry a combination of virulence genes that disrupt the intestinal microbial balance and can cause intra and extra-intestinal infections [6]. Pathogenic E. coli strains synthesize various virulence factors, including several toxins called cyclomodulins such as cytolethal distending toxins (CDT), cytotoxic necrotizing factor (CNF), cycle inhibiting factor, and colibactin. Recent studies have shown that cyclomodulin producing strains are among the B2 phylogenetic group which is more prevalent in people with colorectal cancer [7]. Colibactin is a peptide encoded by the $p k s$ genomic islands, causing DNA double-strand breaks and chromosomal instability in human cells. The efficacy of colibactin and its expression requires bacterial contact with the host cell [8].

In the last decade, increased drug resistance is considered as the most important barrier to successful treatment of infectious diseases and the control of the pathogenicity of microbial agents [9]. The development of new and natural antimicrobial agents due to increased drug resistance in bacterial pathogens is increasing. The cinnamon essential oil contains important compounds including cinnamaldehyde, eugenol, caryophyllene, linalool, alpha-terpineol, coumarin, cineol, and terpinene [10]. Cinnamon has antifungal and antibacterial properties that are related to the cinnamaldehyde. Cinnamaldehyde is an aromatic aldehyde compound and a major component of cinnamon extract (about 65\%). The main advantage of cinnamaldehyde is that it does not need direct contact as antimicrobial activity and classified as a GRAS molecule by the US Food and Drug Administration and approved for use in food [11]. The antimicrobial effects of cinnamon have been proven in various studies [12]. The aim of this study was to investigate the effect of cinnamon and its essential oil (Cinnamaldehyde) on $p k s$ gene expression and microbial biofilm formation of E.coli strains isolated from colon cancer patients, inflammatory bowel disease and healthy subjects.

\section{Methods}

\section{Sample collection}

This study was a cross-sectional study and the E. coli strains isolated from the patients which CRC, inflammatory bowel disease and healthy subjects, during a period from July 2016 to August 2018 in Hamadan, west of Iran. Thirty $p k s$ positive E. coli were collected from colon biopsy specimens of colorectal cancer (13 specimens), inflammatory bowel disease (8 specimens) and healthy subjects (9 specimens).

\section{Culture condition and isolation of $E$. coli}

Biopsy specimens were taken from 50 to $100 \mathrm{mg}$ and were immediately placed in a tube containing $100 \mathrm{ml}$ of sterile phosphate buffer saline (PBS) and transferred to the microbiology laboratory. The biopsy specimens were then washed three times in the laboratory with $10 \mathrm{ml}$ of PBS and centrifuge at $900 \mathrm{~g}$ for $5 \mathrm{~min}$. After homogenous and washing, the samples were cultured on blood agar and MacConkey agar using a sterile loop and incubated at $37^{\circ} \mathrm{C}$ for $24 \mathrm{~h}$. Bacterial strains were confirmed using conventional methods and stored at $-20^{\circ} \mathrm{C}$ [13].

\section{Antibiotic susceptibility test}

Antibiotic susceptibility to ciprofloxacin $(5 \mu \mathrm{g})$, imipenem $(10 \mu \mathrm{g})$, meropenem $(10 \mu \mathrm{g})$, ticarcillin-clavulanic acid (75/ $10 \mu \mathrm{g})$, co-amoxiclav $(20 / 10 \mu \mathrm{g})$, amoxicillin $(10 \mu \mathrm{g})$, amikacin $(30 \mu \mathrm{g})$, piperacillin $(100 \mu \mathrm{g})$, ceftazidime $(30 \mu \mathrm{g})$, trimethoprim-sulfamethoxazole $(1.25 / 23.75 \mu \mathrm{g})$, and gentamicin $(10 \mu \mathrm{g})$ was performed bythe Kirby-Bauer disk diffusion method according to Clinical and Laboratory Standard Institute guidelines (CLSI). Escherichia coli ATCC 25922 was used as quality control strains [14].

\section{Biofilm production assay}

Biofilm production abilities of isolated strains were quantified by the microtiter plate method as previously described using $1 \%$ crystal violet [15]. The absorbance was measured at $620 \mathrm{~nm}$. Each assay was performed in triplicate and the results were reported as mean $\pm \mathrm{SD}$. Tryptic Soy Broth (TSB) medium without bacteria was used as a negative control.

\section{Minimal inhibition concentration}

Minimum inhibitory concentrations (MICs) of cinnamon extract and cinnamaldehyde (Kimia Gostar Research Company, Tehran, Iran) were determined by the broth microdilution method in 96-well plates. Serial concentrations of cinnamon extract and cinnamaldehyde were used. MIC was considered as the last well in which no turbidity was observed. Escherichia coli ATCC 25922 was used as quality control strains. 


\section{Detection of pks genes}

The genomic DNA of bacteria was extracted from overnight cultures of E.coli isolates using the boiling method. All isolates were screened for the presence of the $p k s$ encoding genes, including $c l b B, c l b A$ and $c l b Q$ using a single PCR technique. The list of primers [16, 17] used in the present study has been shown in Table 1.

The PCR reaction mixture contained $1 \mu \mathrm{L}(10 \mathrm{pmol})$ of each primer, $2 \mu \mathrm{L}$ DNA, $25 \mu \mathrm{L}$ PCR Master Mix in a final $50 \mu \mathrm{L}$ reaction volume. DNA amplification was conducted in a thermal cycler (Bio-Rad, USA), under the following conditions: initial denaturation at $94{ }^{\circ} \mathrm{C}$ for 5 min, followed by 35 cycles of denaturation at $94{ }^{\circ} \mathrm{C}$ for $30 \mathrm{~s}$, an annealing temperature for each gene according to Table 1 for $40 \mathrm{~s}$, an extension at $72^{\circ} \mathrm{C}$ for $50 \mathrm{~s}$, followed by a final extension at $72{ }^{\circ} \mathrm{C}$ for $5 \mathrm{~min}$. Electrophoresis of the amplified DNA fragments, along with a $100 \mathrm{bp}$ DNA ladder, was carried out using 2\% agarose gel in TBE buffer.

\section{RNA isolation and quantitative real-time RT-PCR}

In order to investigate the gene expression of $c l b B$ gene, quantitative Real-Time PCR was performed at sub-MIC concentrations of cinnamon extract and cinnamaldehyde. Total RNA was extracted using the Trisol solution. The concentration and optical absorbance of each extracted RNA were confirmed with Nanodrop (Epoch Microplate Spectrophotometer) at $260 \mathrm{~nm} / 280 \mathrm{~nm}$. RNA samples were stored at $-80^{\circ} \mathrm{C}$. In order to elicit the DNA contamination from total isolated RNA, each sample was treated with DNaseI kit (Fermentase Co., USA). The cDNA was synthesized according to the cDNA synthesis kit (Takara, Japan) according to the manufacturer's instruction. RT-PCR was performed in order to cDNA synthesis confirmation. Q-PCR was performed by the SYBR Green gene expression assay (AMPLIQON Co, Denmark) with the Roch system. The primers used in this study were listed in Table 1 and the $16 \mathrm{~s} r R N A$ gene was used as the housekeeping gene. In addition to the melting curve analysis, the specificity of each primer was confirmed by DNA sequencing of Real-Time PCR

\begin{tabular}{|c|c|c|c|}
\hline Genes & Primer sequences $\left(5^{\prime}---3^{\prime}\right)$ & Fragment size (bp) & Reference \\
\hline $\begin{array}{l}c \mid b B-F \\
c l b B-R\end{array}$ & $\begin{array}{l}\text { GCGCATCCTCAAGAGTAAATA } \\
\text { GCGCTCTATGCTCATCAACC }\end{array}$ & 283 & [16] \\
\hline $\begin{array}{l}c l b Q-F \\
c I b Q-R\end{array}$ & $\begin{array}{l}\text { GCAC GATCGGACAGGTTAAT } \\
\text { TAGTCTCGGAGGGATCATGG }\end{array}$ & 308 & [16] \\
\hline $\begin{array}{l}c \mid b A-F \\
C l b A-R\end{array}$ & $\begin{array}{l}\text { AAGCCGTATCCTGCTCAAAA } \\
\text { GCTTCTTTGAGCGTCCACAT }\end{array}$ & 342 & [16] \\
\hline pks & $\begin{array}{l}\text { TCGATATAGTCACGCCACCA } \\
\text { GTCAAGCGAGCATACGAACA }\end{array}$ & 733 & {$[17]$} \\
\hline 16srRNA & $\begin{array}{l}\text { GGTGAATACGTTCCCGG } \\
\text { TACGGCTACCTTGTTACGACTT }\end{array}$ & 144 & {$[16]$} \\
\hline
\end{tabular}

product. The sample contains all of the PCR mixtures except template used as negative template control (NTC). Thermal program was performed by the following steps; 1) the first denaturation was optimized at $95^{\circ} \mathrm{C}$ for $\left.10 \mathrm{~min}, 2\right)$ secondary denaturation was set at $95^{\circ} \mathrm{C}$ for $15 \mathrm{~s}, 3$ ) annealing temperature was set to $60{ }^{\circ} \mathrm{C}$ for $1 \mathrm{~min}$ and finally, 4) $72{ }^{\circ} \mathrm{C}$ was optimized as incubation time for $1 \mathrm{~min}$, step 2-4 was repeated for 40 cycles. Each experiment was repeated three times.

\section{Data analysis}

Statistical analysis was performed using SPSS 24 software. Chi-square and Fischer tests were used to compare group variables. The MIC of cinnamon and cinnamaldehyde was analyzed using Mann-Whitney. A real-time PCR graph was drawn using Graph pad prism software.

\section{Result}

In this study, a total of 30 clinical isolates of $p k s$ positive E. coli were studied. Thirteen, and eight strains isolated from colorectal cancer and inflammatory bowel disease individuals, respectively, and other isolates related to healthy subjects.

\section{Frequency of antibiotic resistance in pks positive E.coli isolates}

The minimum inhibitory concentration (MIC) for 30 clinical isolates of $E$. coli was $32 \mu \mathrm{l}$ per $\mathrm{ml}$ of cinnamon, with no significant difference between isolates. For cinnamaldehyde active ingredient of cinnamon, the maximum value of $\mathrm{MIC}$ was $0.015 \mu \mathrm{l} / \mathrm{ml}$ (30.8\%), and $0.0005 \mu \mathrm{l} / \mathrm{ml}(37.5 \%)$ and $0.015 \mu \mathrm{l} / \mathrm{ml}$ (30\%) was observed in colorectal cancer, inflammatory and healthy isolates, respectively. The MIC for E. coli ATCC 25922 was $0.0000001 \mu \mathrm{L} / \mathrm{ml}$. According to the results of Fig. 1, the highest antibiotic resistance was related to the antibiotics ticarcillin/clavulanic acid, meropenem, amoxicillin and amikacin (93.4\%) and the least to imipenem (16.7\%) and trimethoprim-sulfamethoxazole (23.4\%). The results showed that there was no significant difference between susceptibility and antibiotic resistance of the isolates according to the type of the sample $(p>0.05)$.

\section{Frequency of $c l b B, c l b Q$ and $c l b A$ genes in pks positive $E$. coli isolates}

All thirty $E$. coli isolates were $p k s$ positive and the frequency of $c l b B, c l b Q$ and $c l b A$ were 23.4, 26.7, and $23.4 \%$, respectively. The frequency of $c l b B, c l b Q$ and $c l b A$ positive genes in $p k s$ positive isolates was not statistically significant (Fig. 2). The results showed that there was no significant difference between the antibiotic susceptibility of the isolates $(\mathrm{p}>0.05)$. There was no statistically significant difference between the frequency of 


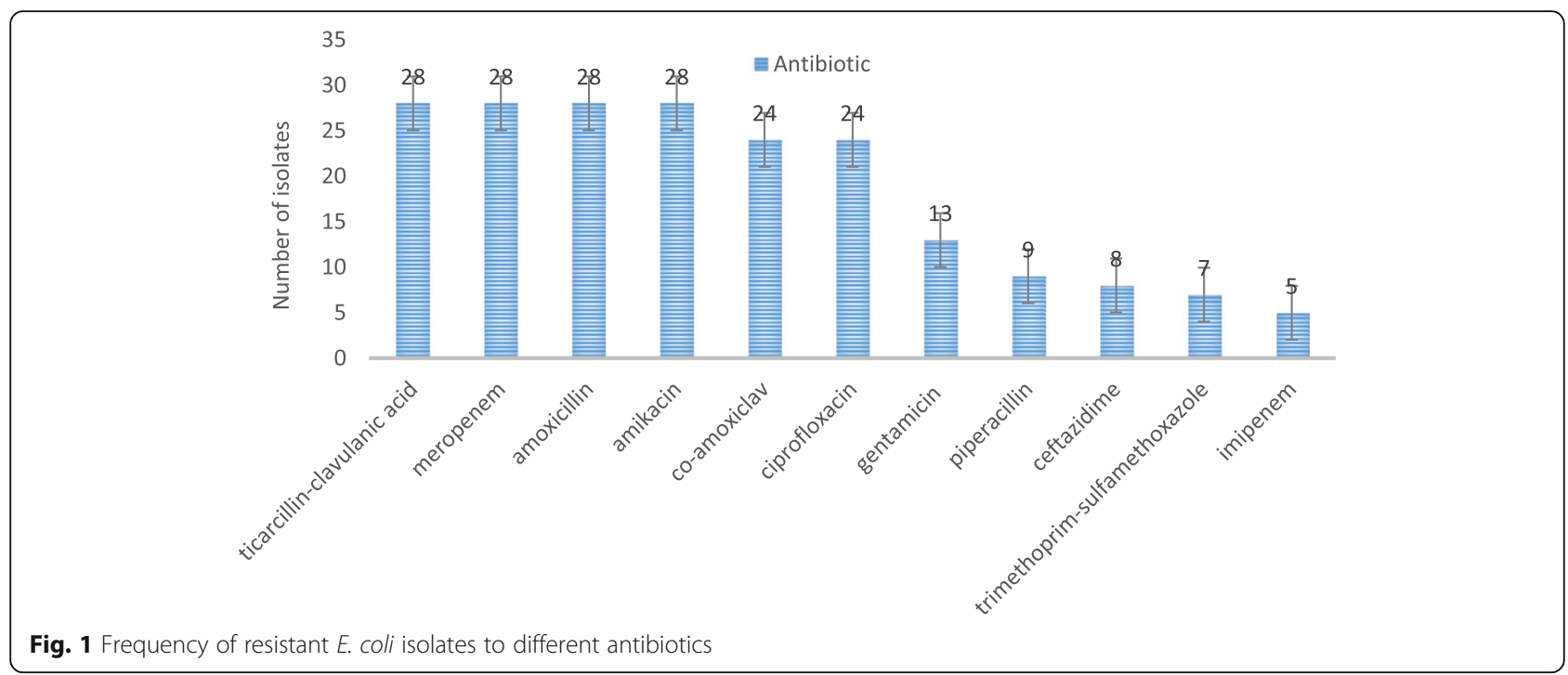

$c l b B, c l b Q$ and $c l b A$ positive genes in the $p k s$ positive $E$. coli isolates by sample type (Fig. 2).

\section{Frequency of microbial biofilm before and after} treatment with cinnamon extract and cinnamaldehyde The results showed, $50 \%$ of the isolates were weakly biofilm producers and $50 \%$ were unable to produce biofilms. After exposure of isolates to cinnamon extract and cinnamaldehyde, 40 and $13.3 \%$ were weakly biofilm producers, respectively (Fig. 3).

\section{Effect of cinnamaldehyde and cinnamon extract on $c l b B$ gene expression in E.coli isolates}

The effect of the Sub-MIC concentration of cinnamaldehyde on $c l b B$ gene expression was evaluated for eight isolates. The 16sRNA gene expression was measured as an internal control. $c l b B$ gene expression was significantly higher in Sub-MIC cinnamaldehyde compared to untreated samples in eight isolates. The four isolates (S1-S4) showed drastically reduced $c l b B$ gene expression (Table 2, Fig. 4).

In the E. coli isolates treated with cinnamon essential oil, the expression of $c l b B$ gene was slightly decreased compared to the control sample, which was also significant (Table 3).

\section{Discussion}

Bacterial infections have long been established as important factors in the etiology of several human cancers. Increased drug resistance is considered as the most important barrier to successful treatment of infectious diseases and the control of the pathogenicity of microbial agents. This investigation presents evidence for the effect of cinnamon extract and its active ingredient cinnamaldehyde on $c l b B$ gene expression and microbial biofilm formation of $E$. coli strains isolated from colon cancer patients.

\section{E Positive $\equiv$ Negative}

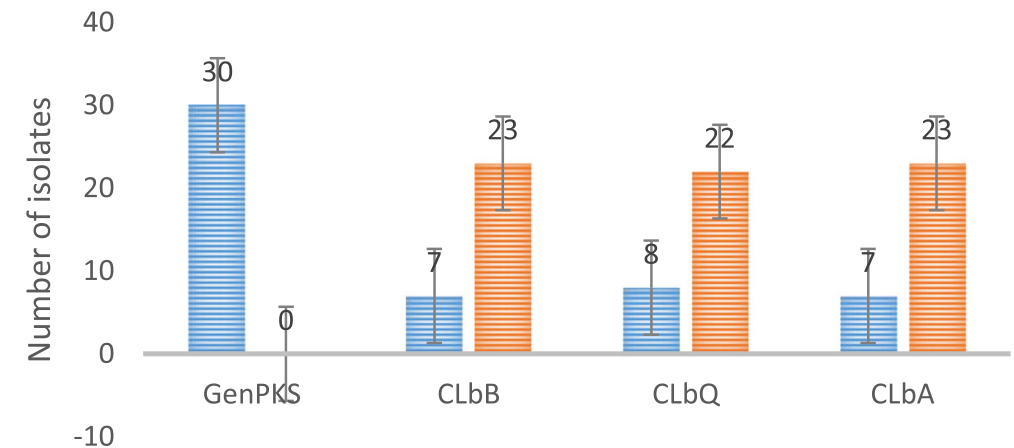

Fig. 2 Frequency of $\mathrm{clbB}, \mathrm{clbQ}$ and $\mathrm{clbA}$ genes in the pks positive E. coli isolatesPositive: The presence of the specific genes in the isolates; Negative: The absence of the specific genes in the isolates. 


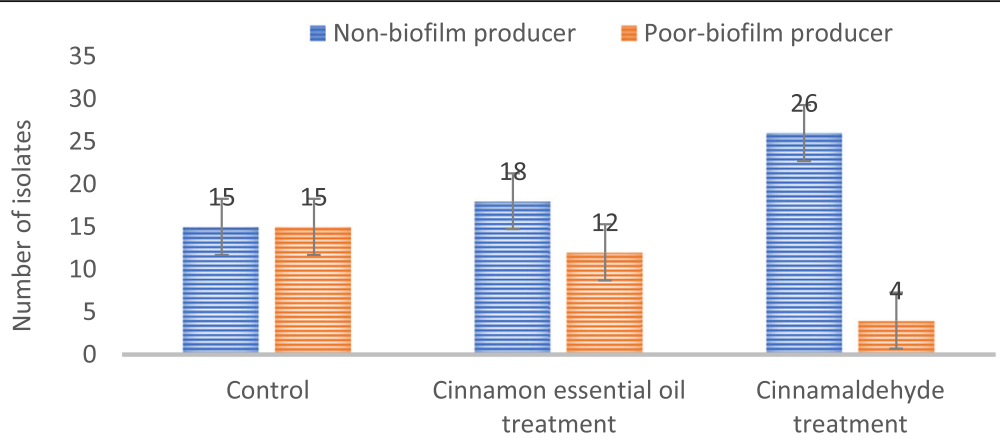

Fig. 3 Frequency of Biofilm producing E. coli isolates after exposure to cinnamaldehyde and cinnamon essential oil

Based on the finding of the present study, the number of our cancer samples was $47.3 \%$, and the prevalence of pks gene in the E. coli isolates was $100 \%$. Our results are in agreement with previous investigations. A study conducted by Suresh et al., in 2018 on the genetic and molecular function of the $p k s$ gene in $462 \mathrm{E}$. coli intestinal pathogens showed that $35(7.6 \%)$ isolates had $p k s$ genes, $97 \%$ of which were pathogenic and biofilm production was strong in $21 p k s$-positive isolates [18]. It was also found that $11 \%$ of these isolates have multidrug resistance which is involved in colibactin resistance. A review study conducted in 2019 by Sadeghi et al. investigated the antimicrobial activity of cinnamaldehyde. They found that cinnamaldehyde, alone or in combination with other plant extracts, had a good antioxidant, antimicrobial and anticancer function. Its anticancer property is due to its effect on the via gene in cancer cells, which has been shown to be in our study the anticancer property of cinnamaldehyde [19]. A study in 2019 by Gilling et al. On the antimicrobial effect of essential oils and extracts on E. coli, examined 11 extracts and essential oils including cinnamaldehyde, which showed a significant antimicrobial effect on E. coli. In this study, the effects of the essential oils were greater than the extracts, and they also increased the susceptibility of the bacteria to antibiotics. According to the results of two studies showed that cinnamaldehyde had a significant antimicrobial effect on E. coli and increased antibiotic susceptibility of this bacterium [20].

Another study was conducted in 2018 by Mohamed et al. on the antibacterial and antibiotic effect of cinnamaldehyde on Acinetobacter baumannii, biofilm production was $86.95 \%$ strong, $52.17 \%$ moderate and $39.17 \%$ poor. They observed that cinnamaldehyde at low concentrations also had antimicrobial activity against $A$. baumannii and the best antibiofilm activity at MIC was 1.2 and $1.4 \mathrm{ppm}$, which reduced biofilm production by $18.5 \%$. They found that cinnamaldehyde had antimicrobial activity against this bacterium, which in our study showed the antimicrobial effects of cinnamaldehyde; However, in our study, the rate of biofilm reduction was higher than that obtained in this study, and the MIC was lower than ours in this study [21]. In 2015 study by Kim et al. in Korea, showed that $0.01 \%$ cinnamon essential oil inhibited $96 \%$ of biofilm formation in Pseudomonas aeruginosa. Also, at this concentration of cinnamon extract, the expression of adhesion and Shiga-toxin production genes in E. coli was reduced up to three times. But in our study, cinnamon extract $(60 \%)$ and cinnamaldehyde (86.7\%) inhibited biofilm production. In the last study, gene expression was also

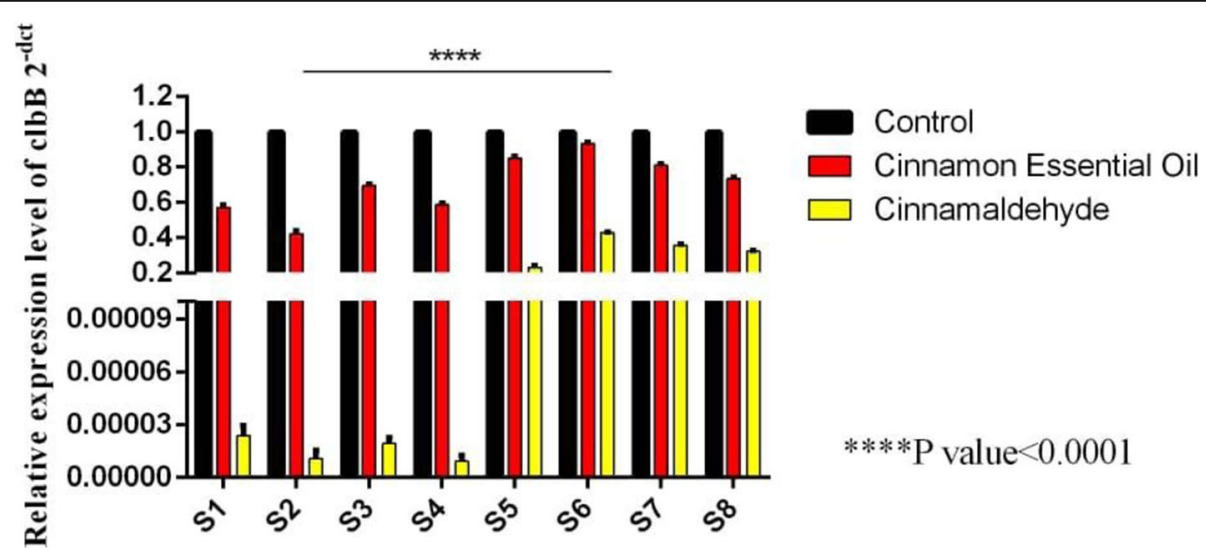

Fig. 4 Comparative expression of clbB gene after treatment with cinnamon and cinnamaldehyde essential oils in samples S1-S8 
Table 2 The effect of cinnamaldehyde on clbB gene expression in E.coli isolates

\begin{tabular}{|c|c|c|c|c|c|c|c|c|}
\hline \multirow{2}{*}{$\frac{\text { isolates }}{1}$} & \multirow{2}{*}{$\begin{array}{l}\text { E.coli isolates source } \\
\text { Cancer }\end{array}$} & \multirow{2}{*}{$\frac{\text { Sub MIC }(\mu \mathrm{l} / \mathrm{ml})}{0.0002}$} & \multirow{2}{*}{$\frac{\text { Mean of CT 16sRNA }}{14.23}$} & \multirow{2}{*}{$\frac{\text { Mean of } C T \mathbf{c l b} \boldsymbol{B}}{18.45}$} & \multirow{2}{*}{$\frac{\text { Mean of CT } \boldsymbol{c l} \boldsymbol{b} B \text { Treat }}{34.05}$} & \multicolumn{2}{|c|}{ Fold change } & \multirow{2}{*}{$\frac{\text { Result }}{\text { Down }}$} \\
\hline & & & & & & $c l b B$ & 0.000018656 & \\
\hline & & & & & & Control & 1.000 & \\
\hline \multirow[t]{2}{*}{2} & Cancer & 0.001 & 14. 14 & 19.34 & 36.02 & $c l b B$ & 0.0000058222 & Down \\
\hline & & & & & & Control & 1.000 & \\
\hline \multirow[t]{2}{*}{3} & Cancer & 0.015 & 14. 33 & 20.99 & 34.02 & $c l b B$ & 0. 000117098 & Down \\
\hline & & & & & & Control & 1.000 & \\
\hline \multirow[t]{2}{*}{4} & Inflammation & 0.015 & 14. 59 & 20.52 & 38.01 & $c l b B$ & 0.000005585 & Down \\
\hline & & & & & & Control & 1. 000 & \\
\hline \multirow[t]{2}{*}{5} & Inflammation & 0.03 & 14. 31 & 32.14 & 34.3 & $c l b B$ & 0. $236,514,412$ & Down \\
\hline & & & & & & Control & 1.000 & \\
\hline \multirow[t]{2}{*}{6} & Healthy & 0.03 & 14. 25 & 31.12 & 32.21 & $c l b B$ & 0. $432,268,616$ & Down \\
\hline & & & & & & Control & 1.000 & \\
\hline \multirow[t]{2}{*}{7} & Healthy & 0.03 & 14. 36 & 33.1 & 34.73 & $c l b B$ & 0. $283,220,971$ & Down \\
\hline & & & & & & Control & 1. 000 & \\
\hline \multirow[t]{2}{*}{8} & Inflammation & 0.06 & 14.87 & 34.76 & 36.98 & $c l b B$ & 0. $230,046,913$ & Down \\
\hline & & & & & & Control & 1.000 & \\
\hline
\end{tabular}

decreased, but the type of genes studied in our research was different from that of Kim et al. [22]. In India, Aparna et al. reported that a concentration of $8-10 \mathrm{mg} / \mathrm{ml}$ of the cinnamon aqueous extract showed a $44 \%$ antibacterial effect against $E$. coli, inhibiting $6.8 \%$ toxin production and inhibiting protease production [23]. In 2012, Packiavathy et al. investigated the effect of methanolic extract of cinnamon on the inhibition of biofilm formation and QS system inhibition in $P$. aeruginosa. The results of this study showed that $4 \mathrm{mg} / \mathrm{ml}$ methanol extract of cinnamon was the lowest concentration that inhibited bacterial growth. Lower concentrations of MIC inhibited the movement and subsequently inhibited the formation of biofilm by the bacterium so that at a concentration of $2 \mathrm{mg} / \mathrm{ml}$ of cinnamon methanol extract inhibited the early stages of biofilm formation in the bacteria under QS system control [24].

In 2019, Malekpour et al. conducted a mixed effect of cinnamon and clove essential oils on $E$. coli isolates

Table 3 The effect of cinnamon essence on $c / b B$ gene expression in E.coli isolates

\begin{tabular}{|c|c|c|c|c|c|c|c|c|}
\hline \multirow{2}{*}{$\frac{\text { isolates }}{1}$} & \multirow{2}{*}{$\begin{array}{l}\text { E.coli source } \\
\text { Cancer }\end{array}$} & \multirow{2}{*}{$\frac{\text { SubMIC }(\mu \mathrm{l} / \mathrm{ml})}{0.0002}$} & \multirow{2}{*}{$\begin{array}{l}\text { Mean of CT 16sRNA } \\
14.54\end{array}$} & \multirow{2}{*}{$\frac{\text { Mean of CT } \mathbf{c l b B}}{18.45}$} & \multirow{2}{*}{$\begin{array}{l}\text { Mean of CT clbB Treat } \\
19.5\end{array}$} & \multicolumn{2}{|c|}{ Fold change } & \multirow{2}{*}{$\frac{\text { Result }}{\text { DOWN }}$} \\
\hline & & & & & & $c l b B$ & $0.554,784,736$ & \\
\hline & & & & & & Control & 1. 000 & \\
\hline \multirow[t]{2}{*}{2} & Cancer & 0.001 & 14.61 & 19.34 & 20.41 & $c l b B$ & 0. $40,332,088$ & DOWN \\
\hline & & & & & & Control & 1. 000 & \\
\hline \multirow[t]{2}{*}{3} & Cancer & 0.015 & 14. 32 & 20.99 & 21.5 & $c l b B$ & $0.683,020,128$ & DOWN \\
\hline & & & & & & Control & 1.000 & \\
\hline \multirow[t]{2}{*}{4} & Inflammation & 0.015 & 14. 23 & 20.52 & 21 & $c l b B$ & 0. $574,349,177$ & DOWN \\
\hline & & & & & & Control & 1. 000 & \\
\hline \multirow[t]{2}{*}{5} & Inflammation & 0.03 & 14. 72 & 32.14 & 32. 88 & $c l b B$ & $0.840,896,415$ & DOWN \\
\hline & & & & & & Control & 1.000 & \\
\hline \multirow[t]{2}{*}{6} & Healthy & 0.03 & 14. 37 & 31.12 & 31.01 & $c l b B$ & 0. $779,228,237$ & DOWN \\
\hline & & & & & & Control & 1. 000 & \\
\hline \multirow[t]{2}{*}{7} & Healthy & 0.03 & 14. 55 & 33.1 & 33.42 & $c l b B$ & 0. $801,069,878$ & DOWN \\
\hline & & & & & & Control & 1. 000 & \\
\hline \multirow[t]{2}{*}{8} & Inflammation & 0.06 & 14. 41 & 34.76 & 34.86 & $c l b B$ & $0.726,986,259$ & DOWN \\
\hline & & & & & & Control & 1. 000 & \\
\hline
\end{tabular}


containing some broad-spectrum beta-lactamase enzymes, which was different from our study [25]. They did not show any growth in 20 strains at concentrations of $1600 \mathrm{ppm}$ and $3200 \mathrm{ppm}$ of cinnamon and clove essential oils, however, in two isolates, MIC of cinnamon essential oil was 400 and $800 \mathrm{ppm}$ and in one isolate, MIC of clove essential oil of $1600 \mathrm{ppm}$. They also showed that the two essential oils had a synergetic effect on the $E$. coli isolates containing the broad-spectrum beta-lactamase TEM gene. In our study, the lowest MIC was $0.00003 \mathrm{ppm}$ for cinnamaldehyde and $31.25 \mathrm{ppm}$ for extract. The results obtained from this study are in good harmony with the most similar studies [21, 23].

\section{Conclusion}

In conclusion, cinnamon extract and cinnamaldehyde have a good antibacterial effect on $E$. coli and can reduce biofilm production and expression of genes that are effective in causing disease. E. coli is one of the most active bacteria causing colorectal cancer that $p k s$ gene plays a significant role in this disease. Real-time PCR can be a gold-standard method for diagnosis. Cinnamon essential oil and active ingredient have various medicinal and therapeutic properties that can reduce the antibiotic resistance of germs, including E. coli.

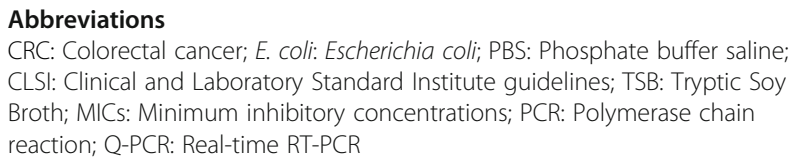
CLSI: Clinical and Laboratory Standard Institute guidelines; TSB: Tryptic Soy Broth; MICS: Minimum inhibitory concentrations; PCR: Polymerase chain reaction; Q-PCR: Real-time RT-PCR

\section{Acknowledgments}

The authors would like to acknowledge the Vice-chancellor of Research and Technology, Hamadan University of Medical Sciences, Hamadan, Iran, and microbiology laboratory staff.

\section{Authors' contributions}

MYA and MT designed the study and drafted the work. FK and RHA contributed to the sample collections and experimental studies. AM analyzed the data. All authors read and approved the final manuscript.

\section{Funding}

The Vice-chancellor of Research and Technology, Hamadan University of Medical Sciences, Hamadan, Iran supported financially the study (Grant Number: 9611107272). The funding body had no role in the design of the study and collection, analysis, and interpretation of data and in writing the manuscript.

\section{Availability of data and materials}

The datasets used and/or analyzed during the current study available from the corresponding author on reasonable request.

\section{Ethics approval and consent to participate}

This study was approved by the ethics committee of Hamadan University of Medical Sciences (No: IRUMSHA. REC.1396.755). The written consent taken from all the participants.

\section{Consent for publication}

Not applicable.

\section{Competing interests}

The authors declare that they have no competing interests.

\section{Author details}

Microbiology Department, Faculty of Medicine, Hamadan University of Medical Sciences, P.O box: 6517838678, Hamadan, Iran. ${ }^{2}$ Department of Community Medicine, Hamadan University of Medical Sciences, Hamadan, Iran. ${ }^{3}$ Department of Pathobiology, Faculty of Veterinary Science, Bu-Ali Sina University, Hamadan, Iran. ${ }^{4}$ Brucellosis Research Center, Hamadan University of Medical Sciences, Hamadan, Iran.

Received: 16 December 2019 Accepted: 11 March 2020

Published online: 30 March 2020

\section{References}

1. Bonnet M, Buc E, Sauvanet P, Darcha C, Dubois D, Pereira B, Déchelotte P Bonnet R, Pezet D, Darfeuille-Michaud A. Colonization of the human gut by E. coli and colorectal cancer risk. Clin Cancer Res. 2014;20(4):859-67.

2. Martin HM, Campbell BJ, Hart CA, Mpofu C, Nayar M, Singh R, Englyst H, Williams HF, Rhodes JM. Enhanced Escherichia coli adherence and invasion in Crohn's disease and colon cancer. Gastroenterology. 2004;127(1):80-93.

3. Huijsdens XW, Linskens RK, Mak M, Meuwissen SG, Vandenbroucke-Grauls CM, Savelkoul PH. Quantification of bacteria adherent to gastrointestinal mucosa by real-time PCR. J Clin Microbiol. 2002;40(12):4423-7.

4. Nadkarni MA, Martin FE, Jacques NA, Hunter N. Determination of bacterial load by real-time PCR using a broad-range (universal) probe and primers set. Microbiology. 2002;148(1):257-66.

5. Touchon M, Hoede C, Tenaillon O, Barbe V, Baeriswyl S, Bidet P, Bingen E, Bonacorsi S, Bouchier C, Bouvet O. Organised genome dynamics in the Escherichia coli species results in highly diverse adaptive paths. PLoS Genet. 2009:5(1):e1000344.

6. Clements JD, Hartzog NM, Lyon FL. Adjuvant activity of Escherichia coli heat-labile enterotoxin and effect on the induction of oral tolerance in mice to unrelated protein antigens. Vaccine. 1988;6(3):269-77.

7. Collins TW, Grineski SE, Chakraborty J, McDonald YJ. Understanding environmental health inequalities through comparative intracategorical analysis: racial/ethnic disparities in cancer risks from air toxics in El Paso County, Texas. Health Place. 2011;17(1):335-44.

8. Guerra L, Guidi R, Frisan T. Do bacterial genotoxins contribute to chronic inflammation, genomic instability and tumor progression? FEBS J. 2011; 278(23):4577-88.

9. World Health Organization. Global status report on alcohol and health 2014. http://apps.who.int/iris/bitstream/10665/112736/1/9789240692763_eng.pdf.

10. Rm D, Ma V, Pilehvarian A, Farzan F. Antinociceptive effect of cinnamon extract on formalin induced pain in rat. J Shahid Sadoughi Univ Med Sci. 2009;17(2):190-9.

11. Gruenwald J, Freder J, Armbruester N. Cinnamon and health. Crit Rev Food Sci Nutr. 2010;50(9):822-34.

12. Singh G, Maurya S, DeLampasona M, Catalan CA. A comparison of chemical, antioxidant and antimicrobial studies of cinnamon leaf and bark volatile oils, oleoresins and their constituents. Food Chem Toxicol. 2007:45(9):1650-61.

13. Anderegg TR, Fritsche TR, Jones RN. Quality control guidelines for MIC susceptibility testing of omiganan pentahydrochloride (MBI 226), a novel antimicrobial peptide. J Clin Microbiol. 2004;42(3):1386-7.

14. Humphries RM, Ambler J, Mitchell SL, Castanheira M, Dingle T, Hindler JA, Koeth L, Sei K. CLSI methods development and standardization working group best practices for evaluation of antimicrobial susceptibility tests. J Clin Microbiol. 2018:56(4):e01934-17.

15. Sung JY, Koo SH, Kim S, Kwon GC. Persistence of multidrug-resistant Acinetobacter baumannii isolates harboring blaOXA-23 and bap for 5 years. J Microbiol Biotechnol. 2016;26(8):1481-9.

16. Shimpoh $T$, Hirata $Y$, Ihara $S$, Suzuki $N$, Kinoshita H, Hayakawa $Y$, Ota $Y$, Narita A, Yoshida S, Yamada A. Prevalence of pks-positive Escherichia coli in Japanese patients with or without colorectal cancer. Gut pathogens. 2017; 9(1):35.

17. Gómez-Moreno R, Robledo IE, Baerga-Ortiz A. Direct detection and quantification of bacterial genes associated with inflammation in DNA isolated from stool. Advances Microbiol. 2014;4(15):1065.

18. Suresh A, Ranjan A, Patil S, Hussain A, Shaik S, Alam M, Baddam R, Lothar W, Ahmed N. Molecular genetic and functional analysis of pksharboring, extra-intestinal pathogenic Escherichia coli from India. Front Microbiol. 2018;9:2631.

19. Sadeghi S, Davoodvandi A, Pourhanifeh MH, Sharifi N, ArefNezhad R, Sahebnasagh R, Moghadam SA, Sahebkar A, Mirzaei H. Anti-cancer effects of 
cinnamon: insights into its apoptosis effects. Eur J Med Chem. 2019;178:

$131-40$.

20. Gilling DH, Ravishankar S, Bright KR. Antimicrobial efficacy of plant essential oils and extracts against Escherichia coli. J Environ Sci Health A. 2019;54(7): 608-16.

21. Mohamed SH, Salem D, Azmy M, Fam NS. Antibacterial and antibiofilm activity of cinnamaldehyde against carbapenem-resistant Acinetobacter baumannii in Egypt: in vitro study. J Appl Pharm Sci. 2018;8(11):151-6.

22. Kim Y-G, Lee J-H, Kim S-I, Baek K-H, Lee J. Cinnamon bark oil and its components inhibit biofilm formation and toxin production. Int J Food Microbiol. 2015;195:30-9.

23. Aparna MS, Yadav S. Biofilms: microbes and disease. Braz J Infect Dis. 2008; 12(6):526-30.

24. Packiavathy IASV, Agilandeswari P, Musthafa KS, Pandian SK, Ravi AV. Antibiofilm and quorum sensing inhibitory potential of Cuminum cyminum and its secondary metabolite methyl eugenol against gram negative bacterial pathogens. Food Res Int. 2012:45(1):85-92.

25. Malekpour B, Kafshdouzan K, Javan AJ, Bejestani MRS. Inhibition of TEMbla producing Escherichia coli isolated from poultry colibacillosis by Cinnamomum camphora and Syzygium aromaticum essential oils singly and in combination. Avicenna J Clin Microbiol Infect. 2019;6(3):16-20.

\section{Publisher's Note}

Springer Nature remains neutral with regard to jurisdictional claims in published maps and institutional affiliations.

Ready to submit your research? Choose BMC and benefit from:

- fast, convenient online submission

- thorough peer review by experienced researchers in your field

- rapid publication on acceptance

- support for research data, including large and complex data types

- gold Open Access which fosters wider collaboration and increased citations

- maximum visibility for your research: over $100 \mathrm{M}$ website views per year

At $\mathrm{BMC}$, research is always in progress.

Learn more biomedcentral.com/submissions 